\title{
First record of the Clam Shrimp Leptestheria venezuelica Daday, 1923 (Crustacea: Brachiopoda: Spinicaudata) from the North of Colombia
}

\author{
Primer registro del Camarón Almeja Leptestheria venezuelica Daday, 1923 (Crustacea: \\ Brachiopoda: Spinicaudata) del Norte de Colombia
}

\author{
Jorge Oliveros-Villanueva * \\ https://orcid.org/0000-0002-9600-4641 \\ jorgeoliveros327@gmail.com \\ Juan Fuentes-Reines \\ https://orcid.org/0000-0001-5809-4271 \\ juanfuentesreines@gmail.com \\ Cesar E. Tamaris-Turizo \\ https://orcid.org/0000-0001-8625-4981 \\ ctamaris@unimagdalena.edu.co \\ Daniel Serna-Macias \\ https://orcid.org/0000-0002-0013-6771 \\ djsernam@hotmail.com \\ Pedro Eslava-Eljaiek \\ https://orcid.org/0000-0002-4779-1589 \\ pemo2002@gmail.com

\section{*Corresponding author}

Grupo de Investigación en Biodiversidad y Ecología Aplicada, Universidad del Magdalena, Carrera 32 No 22-08, Santa Marta, Colombia.

\section{Citación}

Oliveros-Villanueva J, Fuentes-Reines J, Tamaris-Turizo C, Serna-Macias D, Eslava-Eljaiek P. 2021. First record of the Clam Shrimp Leptestheria venezuelica Daday, 1923 (Crustacea: Brachiopoda: Spinicaudata) from the North of Colombia. Revista peruana de biología 28(2): e 18855 (Mayo 2021). doi: http:// dx.doi.org/10.15381/rpb.v28i2.18855

\section{Presentado: $\quad 30 / 10 / 2020$ \\ Aceptado: 28/02/2021 \\ Publicado online: 25/05/2021}

Editor:

Leonardo Romero

\section{Abstract}

Large branchiopods has been distributed in temporary waters around the world, but the knowledge about these organisms in Colombia is poorly known, especially leptesteriids, we report a new record of the Clam Shrimp Leptestheria venezuelica Daday, 1923 from the north of Colombia.

\section{Resumen}

Los grandes branquiopodos se encuentran distribuidos en aguas temporales de todo el mundo, pero el conocimiento de estos en Colombia es poco sobre todo de los leptesteridos, en este trabajo presentamos un nuevo reporte del camaron almeja Leptestheria venezuelica Daday, 1923 para el norte de Colombia.

Keywords:

Spinicaudata; La Guajira; first record; Biodiversity; temporary ponds; Clam shrimp.

Palabras clave:

Spinicaudata; La Guajira; primer registro; Biodiversidad; charcas temporales; camarón almeja.

\section{Introduction}

Large branchiopods are widely distributed in the worldwide, generally associated with temporary water bodies, which are more abundant in the arid and semi-arid regions of the planet (Perez-Bote et al. 2005, Rogers 2013). These primitive crustaceans are constituted by three orders: Anostraca (fairy shrimps), Notostraca (tadpole shrimps) and Diplostraca (Mabidi et al. 2016), this last one comprise more than 200 species described for the world (Tiwari 1966a, 1966b, Martin 1992, Martin \& Davis 2001, Belk et al. 2002, García \& Pereira 2003, Brendonck et al. 2008, Rabet et al. 2012, Rogers \& Padhye 2014, Rogers \& Padhye 2015, Padhye et al. 2015), of which 23 species belong to the family Leptestheriidae (suborder Spinicaudata, spiny clam shrimps) where most of them is represented by the genus Leptestheria. (Brendonck et al. 2008, Babu \& Nandan 2010, Rogers et al. 2020).

In Colombia there is not any valid record of Leptestheria species, nevertheless, this genus has been reported in the Magdalena Valley and the Orinoco River without specifying the species (Roessler 1995). The aim of this paper is to report on the first record of Leptestheria venezuelica in the north of Colombia, which expands distributional range of this species, also a brief description of the specimens found is presented. 


\section{Material and methods}

Study site. - The work was carried out in a temporary pond in Maicao sector, department of La Guajira located between $11^{\circ} 23^{\prime} 04.63^{\prime \prime} \mathrm{N} ; 72^{\circ} 16^{\prime} 31.10^{\prime \prime} \mathrm{W}$ (Fig. 1A) in the north of Colombia, the pond is a product of the temporal rains, the flow of the water disperses through the low áreas of the site, around the pond a sub-xerophytic vegetation dominated by legumes plants, Prosopis juliflora and Acacia farnesiana was observed (Fig. 1B). The rainfalls regime in the area is bimodal, present a high dry period between December and April, in May and June present the minimal rainfalls period, finally, in September start the high rainfalls and extend to November (OrjuelaRojas et al. 2011).

Biological collections. - Biological samples of Leptestheria venezuelica were collected with a zooplankton net (mesh size $=100 \mu \mathrm{m}$ ) in aleatory points of the pond and preserved in $70 \%$ ethanol. Leptestheria venezuelica were processed for taxonomical identification including the examination of the whole specimen and dissection of selected appendages. Dissected appendages were mounted on slides with glycerin and sealed with Canada balsam; then, appendages were photographed using a camera ZEISS model AxioCam ERc 5s under Microscope ZEISS Primo Star and stereo microscope ZEISS Stemi 305 (Carl Zeiss, Oberkochen, Germany). Individuals were measured with the calibrated software ZEN 2 (Blue edition of ZEISS company) in lateral position, from the anterior end of the rostrum to the posterior margin of the telson. The identification of the species recorded herein followed Fryer (1987). Kaji et al. (2014), Shu et al. (2015) and Timms (2016). References were consulted for data on leptestheriids in Daday (1923), Nayar \& Nair (1968), Sars (1900), García \& Pereira (2003) Simhachalam \& Timms (2012), Tiwari (1966a; 1996b) Rogers et al. 2012, Rogers et al. 2020. The examined specimens both dissected (slides) and undissected (vials, ethanol- preserved) samples were deposited at the Museo de Colecciones Biológicas Universidad del Magdalena (CBUMAG) Colombia, where they are available for consultation and further examination.

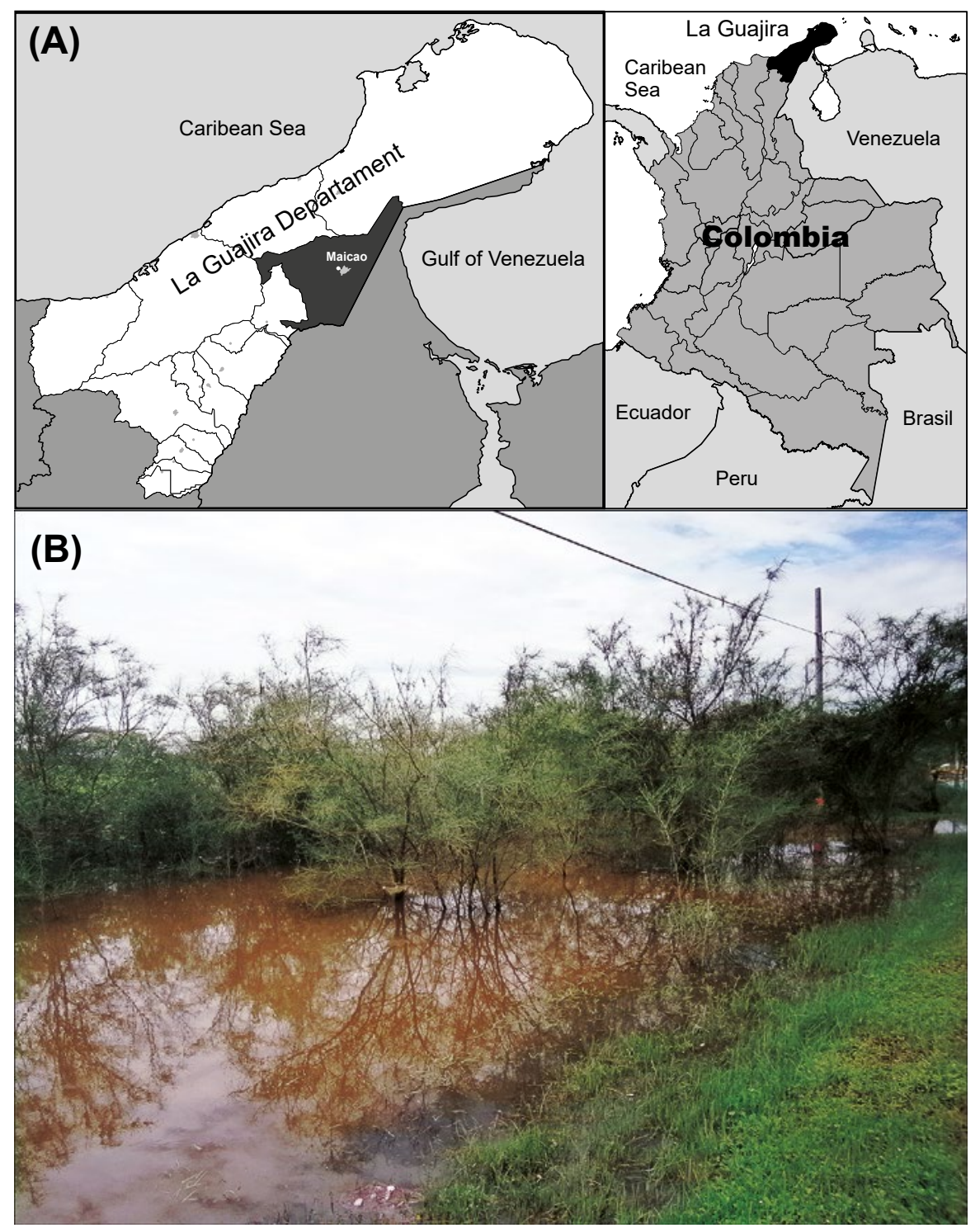

Figure 1. Location of collecting of the Clam Shrimp Leptestheria venezuelica Daday, 1923, new record from Colombia. (A) Location of Maicao, La Guajira, northern of Colombia; (B) photograph of the temporal pond. 


\section{Results}

Material in collection: COLOMBIA, La Guajira, Maicao $18 \mathrm{~km}$ near box culvert roadside pool $\left(11^{\circ} 23^{\prime} 04.63^{\prime \prime} \mathrm{N} ; 7^{\circ} 16^{\prime} 31.10^{\prime \prime} \mathrm{W}\right)$ collected by J,Serna. Nov. 2018; 6 females (CBUMAG:MAC:02010) and 9 males (CBUMAG:MAC:02011) in the Museo de Colecciones Biológicas Universidad del Magdalena.

\section{Taxonomy}

\section{SUBORDER SPINICAUDATA LINDER, 1945}

\section{FAMILY LEPTESTHERIIDAE DADAY, 1923}

\section{GENUS LEPTESTHERIA DADAY, 1913}

\section{Leptestheria venezuelica Daday, 1923}

Female. Carapace. - Female carapace 5.0 - 5.9 length (Fig. 2A; 2C). $(\mathrm{n}=65)$; the umbo is present on anterior margin; arched in the dorsal anterior margin with little granulations, short setaes present in row on the carapa- ce growth lines like that of the male carapace (Fig. 3A). Head: with an angularly shaped rostrum. A rostral apex with wide fornices meet and a well-developed occipital sharp spine anteriorly curved. (Fig. 4A) present a concavity above the eye. First antenna: indistinctly segmented, with $14-18$ lobes bearing sensory setae in frontal margin. (Fig. 5B). Second antenna: indistinctly segmented, with 13 - 15 segments on upper flagellum and 13 14 segments on lower flagellum, each segment with $1-5$ dorsal spines and 3 - 5 ventral long setae (Fig. 4C). Thoracopods: first thoracopod with setose lobe on anterior side (Fig. 8). Female ninth and tenth thoracopod with epipods swollen and cylindrical in shape (female egg mass supporting appendages) (Fig. 7A and 7B). Telson: with two rows of $24-33$ sharp spines, being larger and thin those terminal spines and with much finer spines between them. Telson filaments delicate (two), plumose on distal end, arising behind first telsonal spine. terminal part of the telson ends in two claw-shaped cercopods, dorsally closed in females than in males (Fig. 9B).
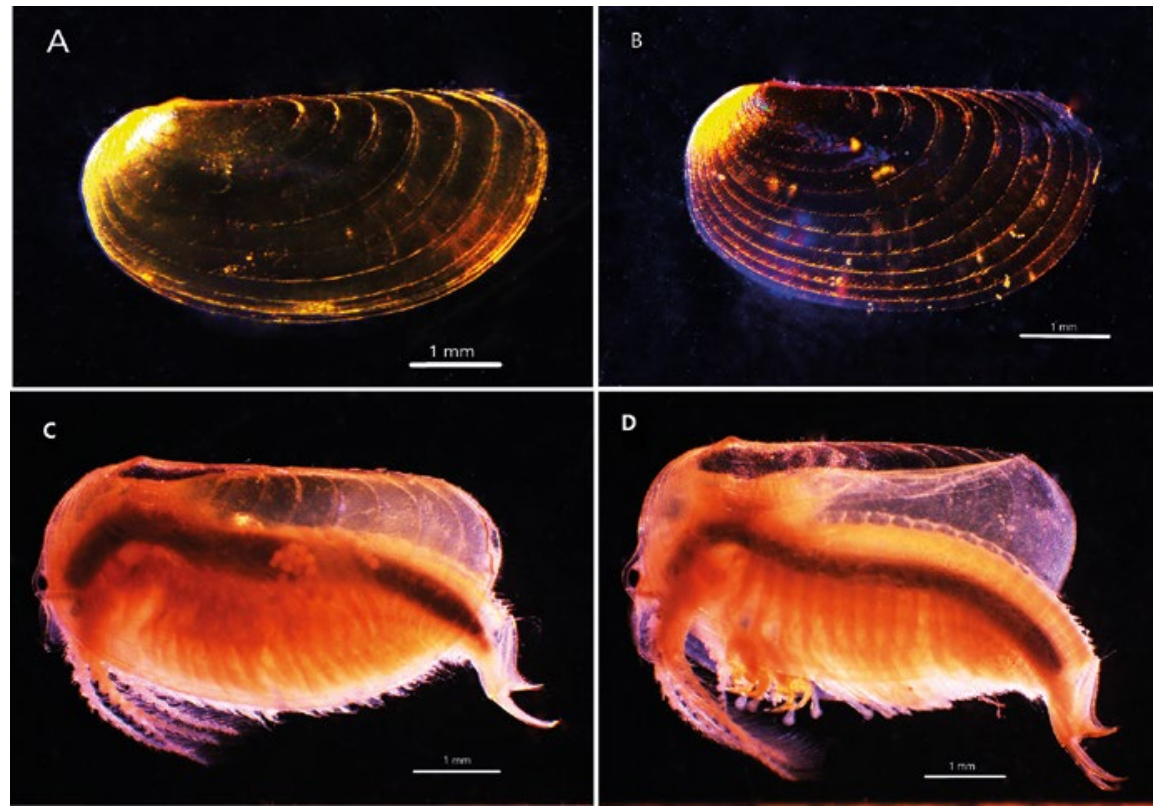

Figure 2. Microphotograph from stereomicroscopy, the left lateral view of the clam shrimps Leptestheria venezuelica showing the carapace female (A), the carapace male (B), habit of the female (C) and the habit of the male (D).
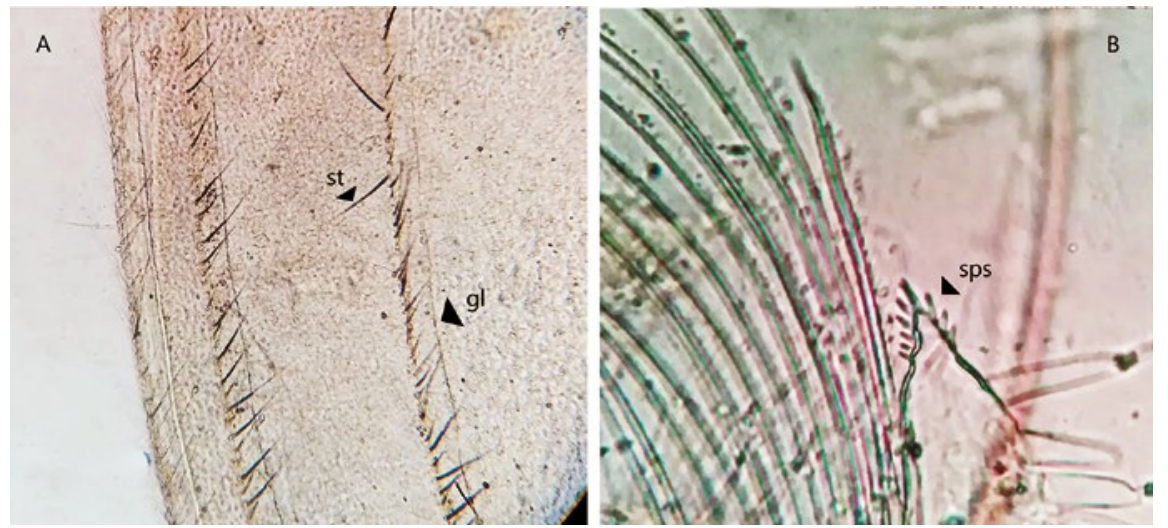

Figure 3. Microphotograph of parts by Leptestheria venezuelica. the grow lines ( $\mathrm{gl}$ ) of the carapace in both sexes (A), the setaes (st) in the lines; the terminal structure of the first endite (sps) in the claspers of the males (B). 

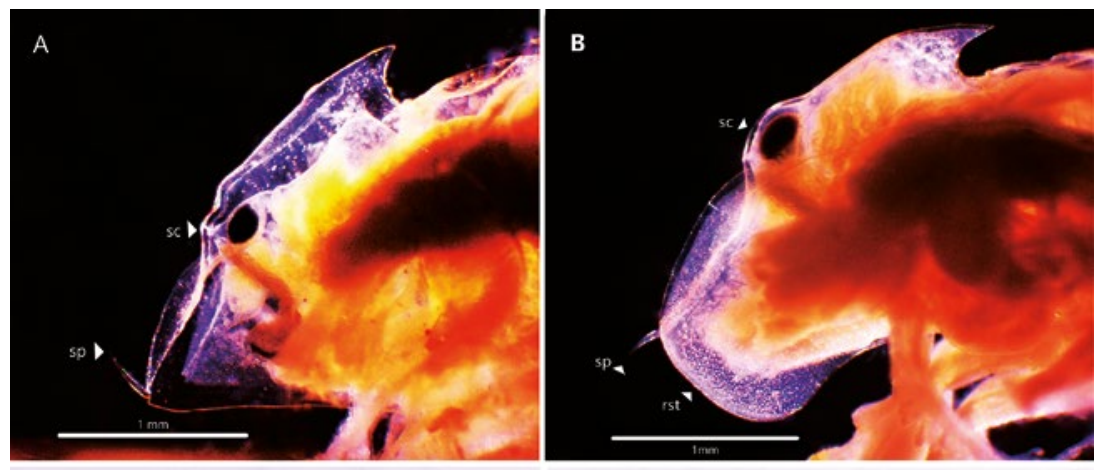

C

D
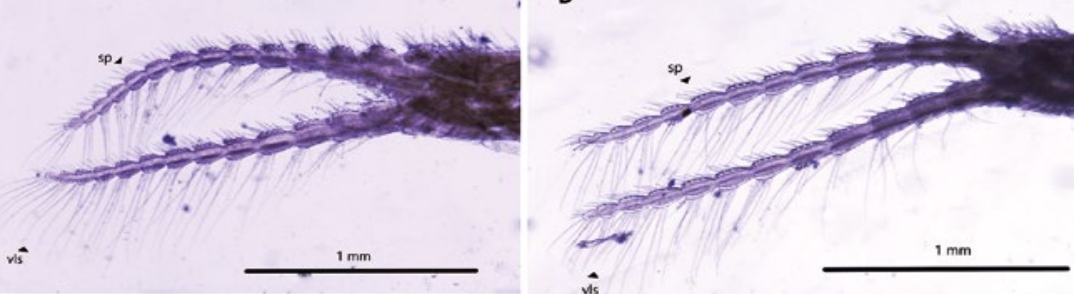

Figure 4. Microphotograph of the parts from Leptestheria venezuelica. Left lateral view of the female head (A) and male head (B) by Leptestheria venezuelica showing the eye (sc), the occipital spine (sp) and the rostrum in Aand B; the second antenna of the female (C) and the second antenna of the male (D) showing the ventral long setaes (vls).

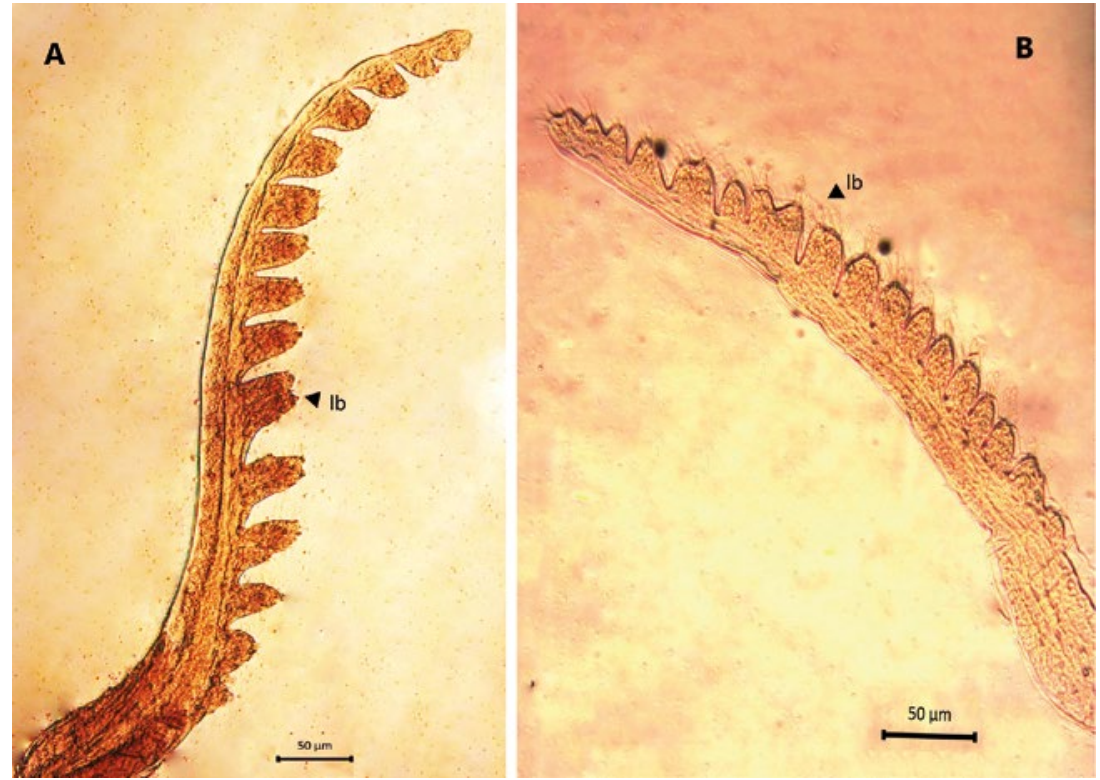

Figure 5. Microphotograph of the first antenna by Leptestheria venezuelica, show the lobes with setaes (Ib) in both sexes, the first antenna of the male (A) and the female (B).

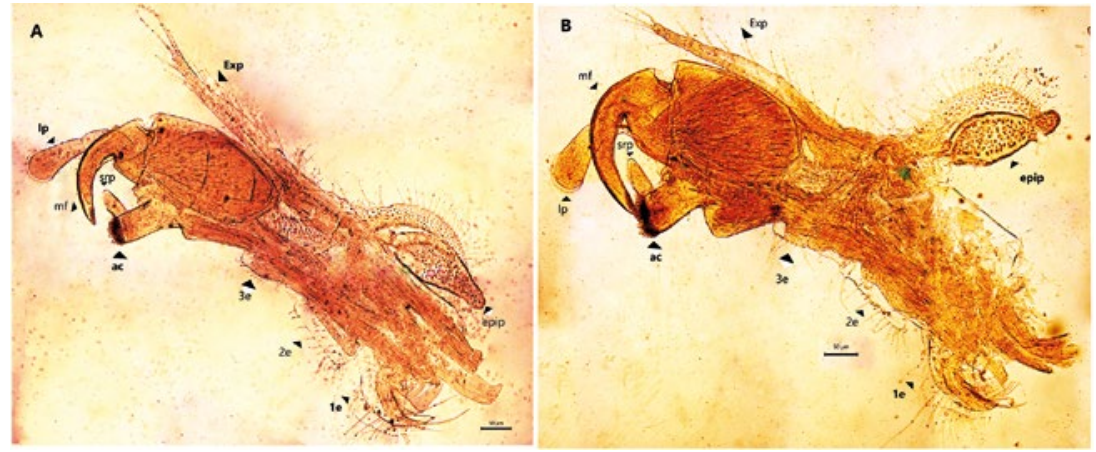

Figure 6. Microphotograph of the right claspers in males of Leptestheria venezuelica. the first clasper (A) and the second (B). Ip: Iong palp; mf: movable finger endopod; srp: short palp; ac: apical club; 1e, 2e and 3e: first, second and third endite respectly; epip: epipodite; Exp: exopodite. 


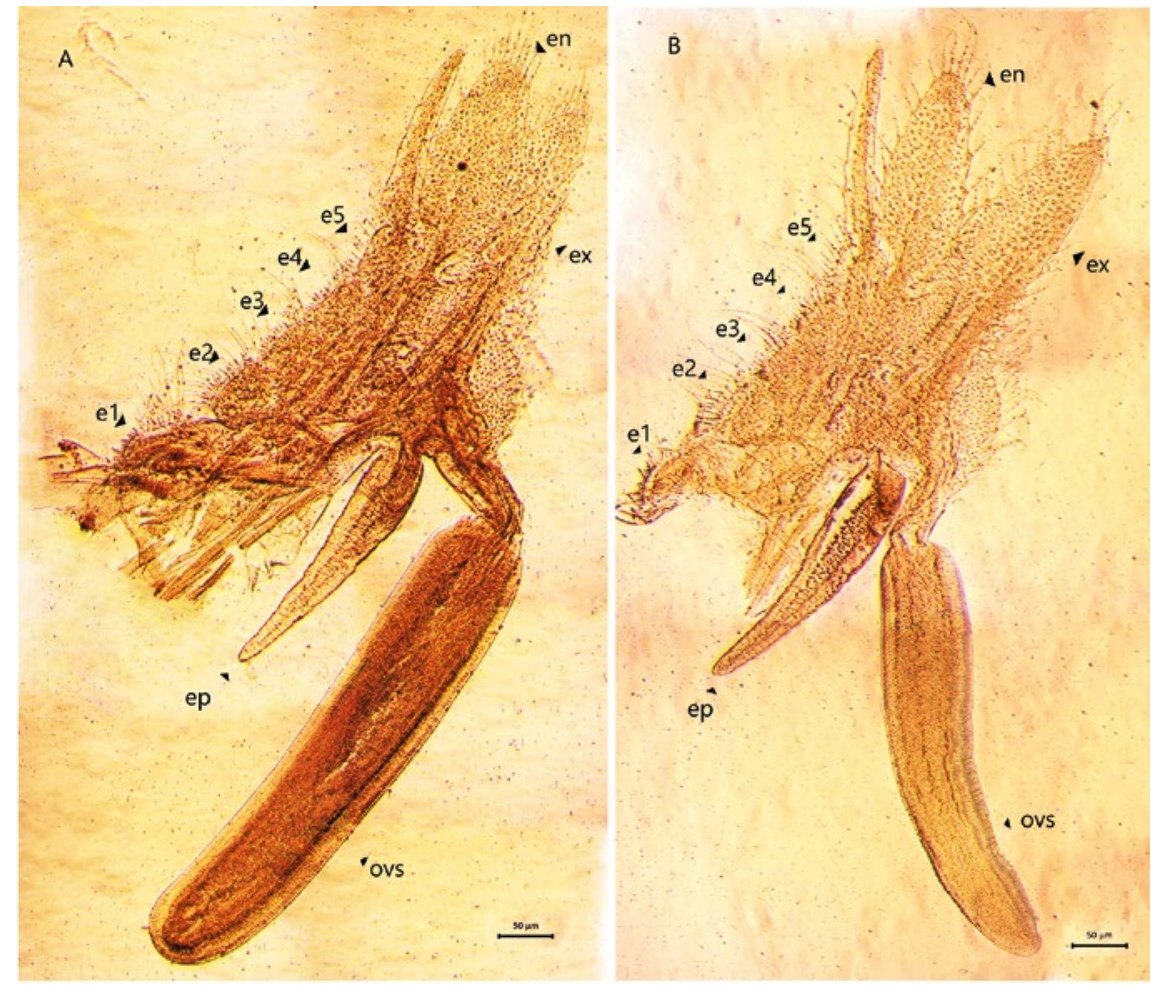

Figure 7. Microphotograph of the right thoracopods in females of Leptestheria venezuelica, the ninth (A) and tenth (B) thoracopods, show the epipodite (ep); the endites (e1-e5); the endopod (en); the exopodite (ex) and the cilintdrical structure for the egg mass supporting (ovs).

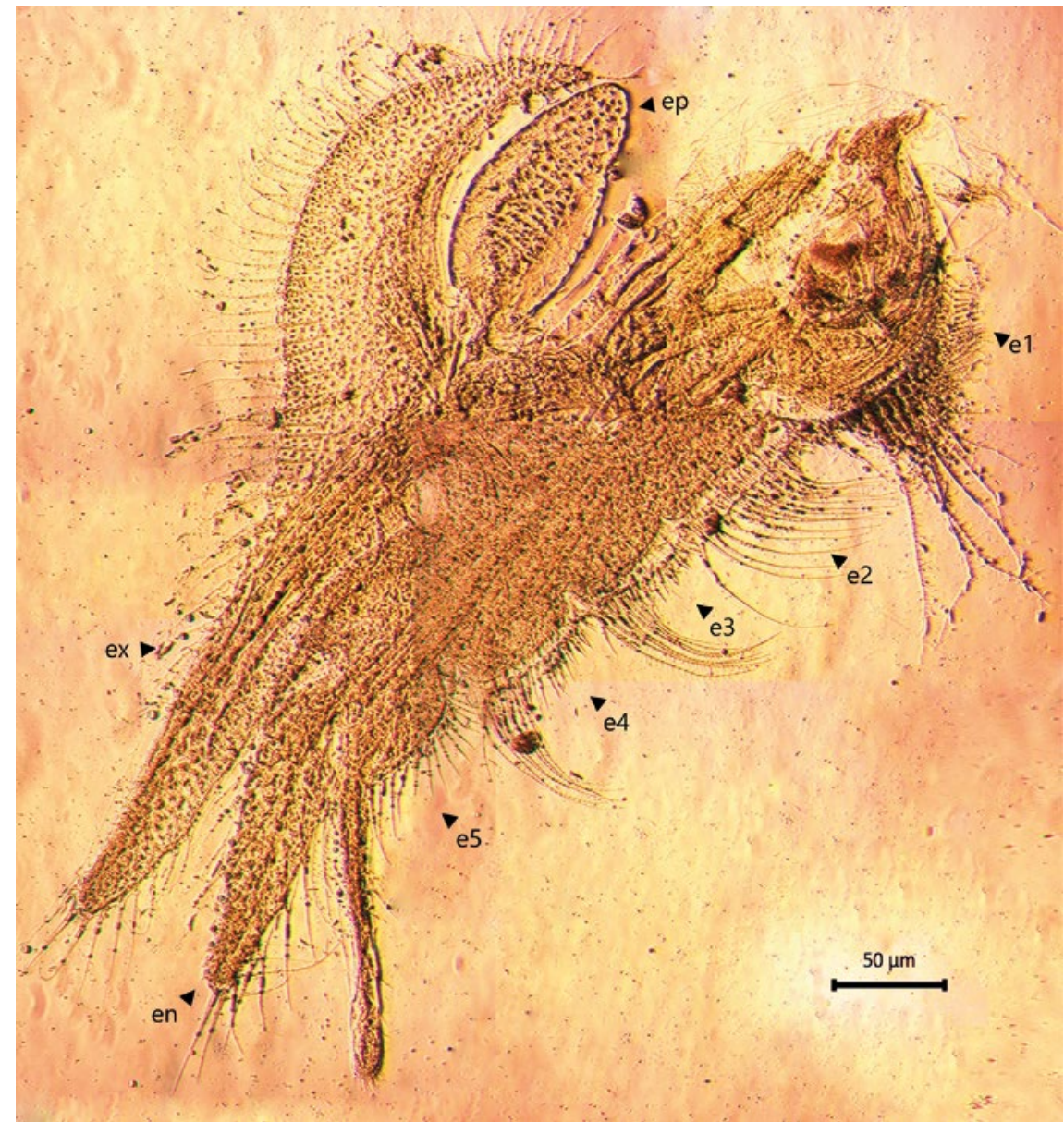

Figure 8. Microphotograph of the right first thoracopod by the female Leptestheria venezuelica, show the endite; the epipodites (ep); the endites (e1-e5); the endopod (en) and the exopodite (ex). 

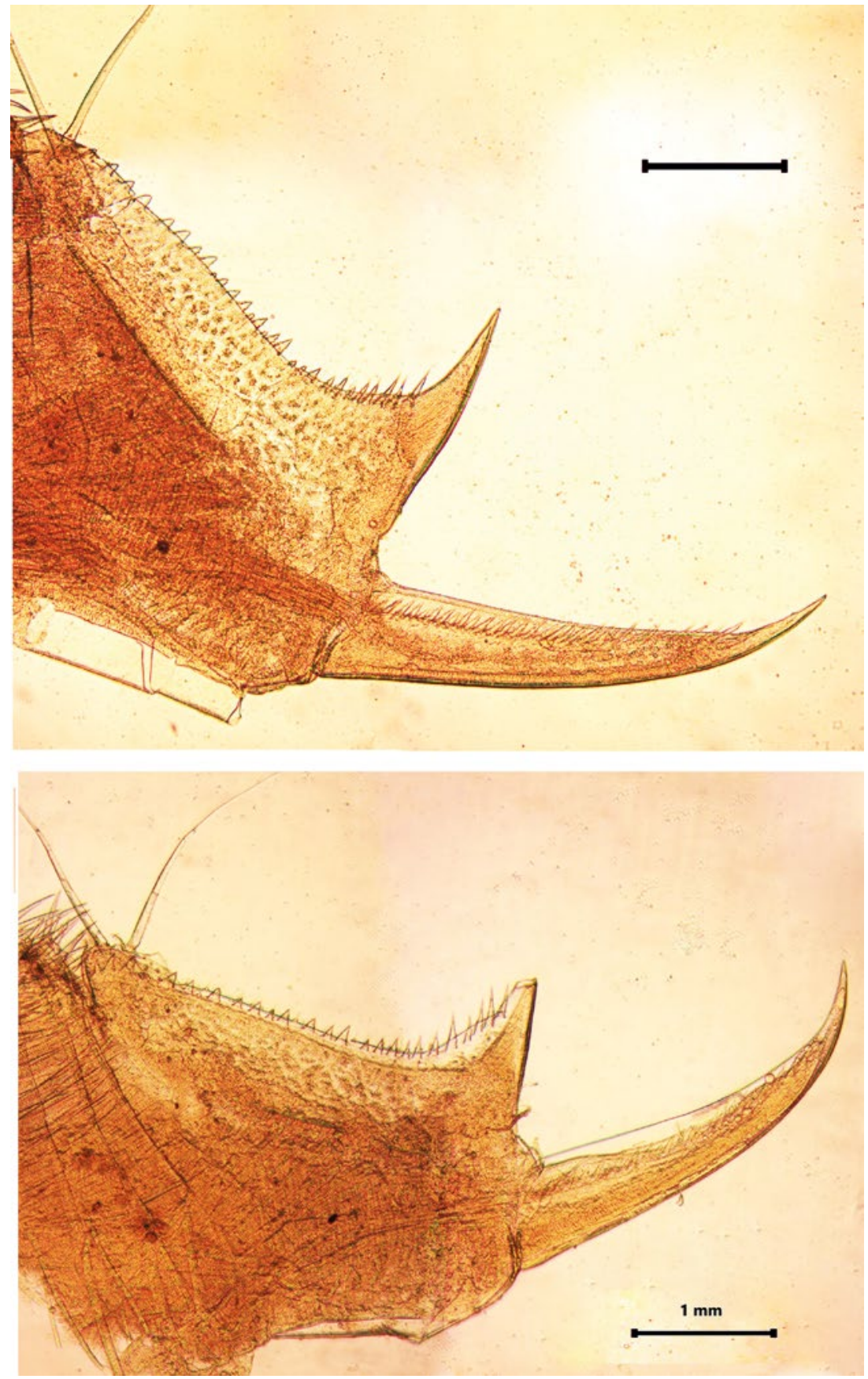

Figure 9. Microphotograph of the telson of the male (A) and the telson of the female (B) by Leptestheria venezuelica, show the row of spines (sp); the cercopod ( $\mathrm{cr}$ ) and the plumose setaes (st).

Males. Carapace: Male carapace $5.0-6.2$ lenght, 2.4 - 3.0 height (Fig. 2B, 2D), $(n=45)$; slightly larger and carapace more rectangular than females. Area between growth lines minutely granulated, ventral margin of carapace with minute spines and setae (Fig. 3A). Head: The rostrum of the male is much broader and blunter, roundly spatuliform in lateral view. with well-developed ventrally arched occipital spine (Fig. 4B). The sharp spine situated a short distance behind the point where the fornices meet, usually straight and directed than the spine of the females. Dorsal margin of the head with shallow concavity above the eye. First Antenna: Male first antenna indistinctly segmented, with $14-16$ lobes bearing sensory setae in frontal margin (Fig. 5A). Second Anten- na: indistinctly segmented, with 13 - 14 segments on upper flagellum and $13-14$ segments on lower flagellum, each segment bearing $3-6$ dorsal spines. All segments with $3-4$ ventral long setae (Fig. 4D). Thoracopods: $22-23$ pairs with the two pair of claspers in males, the first and second thoracopod form a clasper, with strong indentation at base of immovable finger. Movable finger strongly curved with apex acute, the first (Fig. 6A) thicker than the second thoracopod (Fig. 6B); the first endite of the clasper present a tip with diminute spines, characteristic of the genre (Fig. 3B). The second and third endite (e2 and e3) have a filtering function in the anterior thopopods, present variable setaes; Distal end bearing noticeably short blunt spines on ventral margin; Endite 
5 immovable finger stout, with strong thick acute spines on clasping border. Endite 4 stout, with simple terminal setae; palp (edite 5) stout, with two segments, bearing setae only on distal segment, arcuate, of two palpomeres, lightly. (endopod) broad basally, tapering and hooked distally; apex with many small scales; large palp, palpomere length subequal in both claspers; distal palpomere (endite 5 outgrowth) slightly elongated, apex with fine setae; small palp (endite 6 outgrowth) cylindrical, nearly twice as long as broad, directed anteriorly or slightly posteriorly, with apex covered with fine setae; palm (endite 6) broadly rectangular, projecting slightly obtusely, gripping area covered with small roughly conical, blunt tipped spines, increasing in size posteriorly.

Total length of palp slightly exceeding half length of movable finger. Endite 1 strongly curved, with acute tip bearing two serrate terminal spines. Endites 2 and 3 lobulate, with pedunculate setae.

Telson: Male telson with two rows of 28 - 32 sharp spines much finer spines between them, being larger and thin those terminal spines. Telson filaments delicate, plumose on distal end, arising behind first telsonal spine (Fig. 9A).

\section{Discussion}

The species herein recorded in addition to the records about leptestheriids by Roesser (1995) in Colombia enrich the knowledge of the leptestheriid-fauna of the contry and promote the search of important information about the diversity of taxa. Leptestheria venezuelica described for first time by Daday (1923) has been recorded in Aruba, Venezuela and recently in Chile (Belk et al. 2002, García \& Pereira 2003, Rogers et al. 2020), demonstrates the gradual widening of distribution of the species without lose their endemism for South America.

\section{Literature cited}

Babu K, Nandan S. 2010. Two new clam shrimp species (Crustacea: Branchiopoda: Spinicaudata) from Kerala, India. Zootaxa, 2713, 55-64. https://doi.org/10.11646/ zootaxa.2713.1.4

Belk D, Belk MS, Reading K. 2002. Survey of large branchiopods on Aruba and observations on taxonomic characters in Leptestheria (Spinicaudata). Hydrobiologia, 486, 115118. https://doi.org/10.1023/A:1021386315348

Brendonck L, Rogers RC, Olesen J, Weeks S, Hoeh WR. 2008. Global diversity of large branchiopods (Crustacea: Branchiopoda) in freshwater. Hydrobiologia, 595, 167-176. https://doi.org/10.1007/s10750-007-9119-9

Daday E. 1923. Monographie systématique des Phyllopodes Conchostracés. Deuxiéme Partie, Annales des Sciences naturelles, Zoologie, 10 esérie, 10, 331-390.

Fryer, G. 1987. Una nueva clasificación de crustaceos branquiopodos. Revista Zoológica de la Sociedad Linneana 91: 357-383.

García J, Pereira G. 2003. A Review Of The Clam Shrimp Family Leptestheriidae (Crustacea: Branchiopoda: Spinicaudata) From Venezuela, With Descriptions Of Two New Species. Zootaxa. https://doi.org/10.11646/zootaxa.208.1.1
Kaji T, Fritsch M, Schwentner M, Olesen J, Richter S. 2014. Male claspers in clam shrimps (Crustacea, Branchiopoda) in the light of evolution: A case study on homology versus analogy. Journal of Experimental Zoology Part B: Molecular and Developmental Evolution. 322(5):269280. https://doi.org/10.1002/jez.b.22574

Mabidi A, Bird MS, Perissinotto R, Rogers DC. 2016. Ecology and distribution of large branchiopods (Crustacea, Branchiopoda, Anostraca, Notostraca, Laevicaudata, Spinicaudata) of the Eastern Cape Karoo, South Africa. ZooKeys 618: 15-38. https://doi.org/10.3897/ zookeys.618.9212

Martin, J.W. 1992. Branchiopoda. In: Harrison, F.W., \& Humes, A. G. (Eds.) Microscopic Anatomy of Invertebrates. Volume 9: Crustacea. Wiley-Liss, New York, NY, pp. 25-224.

Martin JW, Davis GE. 2001. An updated classification of the Recent Crustacea. Natural History Museum of Los Angeles County Science Series, 39, 1-124.

Nayar CKG, Naire KKN. 1968. Sobre una colección de Conchostraca (Crustacea: Branchiopoda) del sur India, con la descripción de dos nuevas especies. Hydrobiologia , 32, 219-224. http://dx.doi.org/10.1007/bf00179552

Orjuela-Rojas AM, Villamil CA, Sanjuan-Muñoz A. 2011. Cobertura y Estructura de los Bosques de Mangle en la Baja Guajira, Caribe Colombiano. Boletin de investigaciones marinas y costeras. 40(2): 381-399. https://doi. org/10.25268/bimc.invemar.2011.40.2.117

Padhye SM, Rabet N, Ghate H. 2015. First faunal inventory of large branchiopods (Crustacea: Branchiopoda) of Western Maharashtra, India with taxonomical and distributional comments. Zootaxa, 3904 (2), 208-222. https://doi.org/10.11646/zootaxa.3904.2.2

Pérez-Bote J, Muñoz E, Méndez R, Roso AB, Martín A, Romero J, López M. 2005. Grandes branquiópodos: importancia ecológica y conservación. Ecosistemas. 2005/2.

Sars GO. 1900. On some Indian Phyllopoda. Archiv for Mathematik og Naturvidenskab, 22, 3-30.

Rabet N, Godinho LB, Montero D, Lacau S. 2012. Exploration of the egg shell structure of three Neotropical Eulimnadia species: a new insight into genus taxonomy (Crustacea: Branchiopoda: Spinicaudata), Studies on Neotropical Fauna and Environment, 47 (3), 1-6. https:// doi.org/10.1080/01650521.2012.711967

Roessler EW. 1995. Review of Colombian Conchostraca (Crustacea) - ecological aspects and life cycles - families Lynceidae, Limnadiidae, Leptestheriidae and Metalimnadiidae. Hydrobiologia. 298(1):125-132. https:// doi.org/10.1007/BF00033807

Rogers D, Rabet N, Weeks S. 2012. Revision of the Extant Genera of Limnadiidae (Branchiopoda: Spinicaudata). Journal of Crustacean Biology. 32. 827-842. https:// doi.org/10.1163/193724012X637212

Rogers D, Padhye SM. 2015. Review of the large branchiopod crustacean fauna of the Indian Subcontinent (Anostraca, Notostraca, Laevicaudata, Spinicaudata, Cyclestherida). Journal of Crustacean Biology, 35, 392-406. https://doi.org/10.1163/1937240X-00002327

Rogers D, Severo-Neto F, Vieira Volcan M, De los Ríos P, Epele L, Ferreira A, Rabet N. 2020. Comments and records on the large branchiopod Crustacea (Anostraca, Notostraca, Laevicaudata, Spinicaudata, Cyclestherida) of the Neotropical and Antarctic bioregions, Studies on Neotropical Fauna and environment. https://doi.org/ $\underline{10.1080 / 01650521.2020 .1728879}$ 
Simhachalam G, Timms BV. 2012. Two new species of Spinicaudata (Crustacea: Branchiopoda) in south India with a key to Leptestheriella and Eocyzicus. Zootaxa, 3161, 20-36. https://doi.org/10.11646/zootaxa.3161.1.2

Shu S, Rogers DC, Chen S, Yang J. 2015. Two new species of Clam Shrimp (Branchiopoda: Spinicaudata) from Yunnan province, China. Journal of Crustacean Biology, 35 (3), 454-460. https://doi. org/10.1163/1937240X-00002338

Timms BV. 2016. A partial revision of the Australian Eulimnadia Packard, 1874 (Branchiopoda: Spinicaudata: Limnadiidae). Zootaxa, 4066 (4), 351-389. https://doi. org/10.11646/zootaxa.4066.4.1

Tiwari KK. 1966a. Conchostraca from the Sambhar Lake, Rajasthan. Proceedings of the Zoological Society, Calcutta, 19, 67-76.

Tiwari KK. 1996b. Chapter 13: Branchiopod Crustacea of the Rajasthan Desert. In: Ghosh, A.K., Baquri, Q.H. \& Prakash, I. (Ed.), Faunal Diversity in the Thar Desert: Gaps in Research. Scientific Publishers, Jodhpur, pp. 113-129.

\section{Agradecimientos / Acknowledgments:}

Our special Thanks to Biologist researchers of Grupo de Investigación en Biodiversidad y Ecología Aplicada GIBEA, Thanks to the students of the University of Magdalena Raúl Cayón, Daniel Alemán, and the biologist José Daniel Quiñonez, for their help in the field work.

\section{Conflicto de intereses / Competing interests:}

The authors declare no conflict of interest.

\section{Rol de los autores / Authors Roles:}

Contribution Information: JO-V: research, data curation, formal analysis, Writing- Preparation of the original draft. JF-R research, formal analysis, visualization, and Writing - Preparation of the original draft. D S-M: Research and Writing-Preparation of the original draft. CET-T: research, surveillance and Writing- Preparation of the original draft. PE-E: surveillance, resources, help in methodology and acquisition of funds.

\section{Fuentes de financiamiento / Funding:}

This work is part of the project "Redes tróficas de charcas estacionales en el norte del departamento de la Guajira. Colombia" (Proyecto número 16ED16C3F13, PIs: R. Cayón Reyes) financed by FONCIENCIAS of the Universidad del Magdalena.

Aspectos éticos / legales; Ethics / legals:

Authors declare that they did not violate or omit ethical or lega norms in this research. 